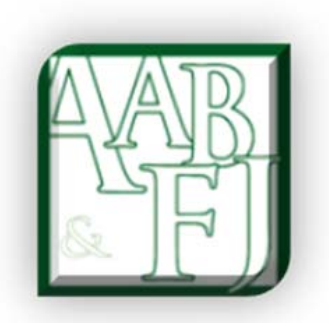

\title{
Editorial: AABFJ Volume 11, Issue 3, 2017
}

\author{
Gregory Jones $^{1}$, Claire Beattie ${ }^{2}$ and Afzalur Rashid ${ }^{3}$
}

The September 2017 issue of AABFJ includes articles from the areas of accounting, finance, economics tax, and financial planning. Authors for this issue are from Institutions in Australia, New Zealand, USA, Pakistan, Thailand, Egypt, Malaysia and India. The Guest Editors for this issue of AABFJ hail from Australia, New Zealand and Bangladesh. It is a great pleasure to be involved in a truly international journal issue.

From the accounting and tax disciplines, Edeigba and Amenkhienan (2017) investigate the implications of the gap between International Financial Reporting Standards and New Zealand International Financial Reporting Standards on financial reporting transparency, accountability and corporate fraud using content analysis. The authors suggest that this gap may result in reduced transparency in disclosure practices of non-listed entities in New Zealand. Next, Passant provides a historical analysis of the interrelationship between revolution and tax in the context of the American Revolution. This article reminds us how notions of class and class struggle influence current discussions and debates about tax and history.

Two articles contribute to the financial planning discipline by work studying insurance and financial literacy. Shusha (2017) studied the effect of demographic characteristics on financial risk tolerance among Egyptians. This article provides results from a study of 386 respondents representing different segments of Egyptian people. Using hierarchical regression analysis, the results demonstrated that there were significant effects of gender, age, educational level and annual income on financial risk tolerance. The author finds that financial literacy is found to moderate the relationship among demographic characteristics of individuals, and their tendency to accept risk. Mitra (2017) analyses the impact of economic, demographic and cultural factors on life insurance consumption in 28 European countries, from 2009-2014 (post financial crisis). Notably the work encompasses many of the emerging Eastern European economies where significant insurance sectors reforms have recently taken place. Two demographic factors, population and education, and two cultural factors, individualism and long term orientation were found to impact insurance consumption in the selected countries.

\footnotetext{
${ }^{1}$ University of Southern Queensland, Australia

${ }^{2}$ University of Southern Queensland, Australia

${ }^{3}$ University of Southern Queensland, Australia
} 
Finance and economics are represented in this issue by Shah and Khan (2017) who investigate the effects of mergers and acquisitions on operating performances of acquirer banks in Pakistan. Financial Ratio Analysis is used to determine the effects of mergers and acquisitions on the operating performance of the acquirer banks. This research provides evidence that firm performances deteriorate in the performances in the post-merger period. The authors recommend that these banks would be better served by expanding their networking rather than participating in merger deals. Wattanakul and Watchalaanun (2017) examine the relationship between Laos's GDP, Thailand's direct investment in Laos and Laos's export into Thailand using the vector error correction model. The results suggest a short run unidirectional relationship from Laos's GDP to Laos's exports to Thailand. A policy suggestion arising from this paper is that Laos's Government should consider distributing income from the group benefitting from this situation into the overall Lao economy. Providing a behavioural perspective on Indian risk attitudes, Dasgupta analyses the rates of returns on assets and equity of 50 CNX NIFTY companies over a 5 year period. The findings provide practical implications for current and prospective investors in these companies.

\section{References}

Dasgupta, Ranjan, Behavioral Implications of Risk-Return Associations: An Application of, Australasian Accounting, Business and Finance Journal, 11(3), 2017, 103-126. doi:10.14453/aabfj.v11i3.8

Edeigba, Jude and Amenkhienan, Felix, The Influence of IFRS Adoption on Corporate Transparency and Accountability: Evidence from New Zealand, Australasian Accounting, Business and Finance Journal, 11(3), 2017, 3-19. doi:10.14453/aabfj.v11i3.2

Mitra, Aditi, Influencers of Life Insurance Investments: Empirical Evidence from Europe, Australasian Accounting, Business and Finance Journal, 11(3), 2017, 87-102. doi:10.14453/aabfj.v11i3.7

Passant, John, Taxation and the American Revolution, Australasian Accounting, Business and Finance Journal, 11(3), 2017, 20-29. doi:10.14453/aabfj.v11i3.3

Shah, Burhan Ali and Khan, Niaz, Impacts of Mergers and Acquisitions on Acquirer Banks' Performance, Australasian Accounting, Business and Finance Journal, 11(3), 2017, 30-54. doi:10.14453/aabfj.v11i3.4

Shusha, Amir Ali, Does Financial Literacy Moderate the Relationship among Demographic Characteristics and Financial Risk Tolerance? Evidence from Egypt, Australasian Accounting, Business and Finance Journal, 11(3), 2017, 67-86. doi:10.14453/aabfj.v11i3.6

Wattanakul, Thanet and Watchalaanun, Tanawat, The Relationship between Foreign Direct Investment from Thailand and Export on the Economic Growth of Laos, Australasian Accounting, Business and Finance Journal, 11(3), 2017, 55-66. doi:10.14453/aabfj.v11i3.5 